\title{
Root Development of Tissue-Cultured Papaya Shoots in Several Rooting Substrates
}

\author{
Padungsak Suksa-Ard, Ikuo Kataoka, Kenji BepPu, Yukihiro Fujime \\ and Suranant SubHADRABANDHU* \\ Faculty of Agriculture, Kagawa University, Miki, Kagawa 761-0795, Japan \\ *Faculty of Agriculture, Kasetsart University, Bangkhen, Bangkok 10900, Thailand
}

(Received February 22, 1998)

\begin{abstract}
The influence of the rooting substrate on the root development of papaya in vitro was studied. The rooting of microcuttings started after the swelling of the basal ends. After 4 weeks of culture, the rooting rate was highest in the starch medium at $96 \%$, followed by the agar, rockwool and vermiculite media. In the gellan gum medium, only $8 \%$ of the microcuttings rooted. Anatomically, hypertrophy of subepidermal cells and occurrence of cracking in the epidermis were observed in the starch, agar and gellan gum media. On the other hand, no structural abnormalities were detected in roots formed in the vermiculite and rockwool media. Although, the rooting rate was enhanced with increasing concentrations of agar and gellan gum, the abnormal structures still persisted in both media even when higher concentrations were applied.
\end{abstract}

\section{INTRODUCTION}

Difficulty in acclimatization of micropropagated plantlets often becomes a practical problem. Especially in papaya, the plantlets tend to decline easily during acclimatization and grow poorly even after being transplanted to the field (De Winnaar, 1988). Recently, several researchers pointed out that the physical and chemical nature of rooting substrate considerably affected the rooting (Kataoka, 1994; Teo and Chen, 1994; Huang et al., 1995). In papaya, the morphological abnormalities were found in the roots formed in the ordinary agar medium (Kataoka, 1994). This may account for the malfunction of the roots and debilitating effect on the plantlets.

In this paper, to find the appropriate rooting substrate for tissue-cultured papaya shoots, the influences of several rooting substrates on the rooting rate and the morphological characteristics of the roots were studied.

\section{MATERIALS AND METHODS}

Establishment of proliferation culture and preparation of microcuttings. Shoot tip culture of Carica papaya L. (dioecious strain, female plant) was established by the methods previously reported (Kataoka and Inoue, 1991) on Murashige and Skoog (1962) (MS) basal medium supplemented with $1 \mu \mathrm{M}$ 6-benzylamino purine (BA), $30 \mathrm{~g} \cdot 1^{-1}$ sucrose and $10 \mathrm{~g} \cdot 1^{-1}$ agar. The cultures were incubated at $27 \pm 1^{\circ} \mathrm{C}$ under a photoperiod of $16 \mathrm{~h}$ at $40 \mu \mathrm{mol} \cdot \mathrm{m}^{-2}$. $\mathrm{s}^{-1}$ with cool white fluorescent tubes. The proliferation culture was maintained by dividing 
the shoot mass and subculturing every 4 weeks.

Actively growing shoot tips with 2 axillary buds $5 \mathrm{~mm}$ long were placed in $300 \mathrm{ml}$ Erlenmeyer flask containing $100 \mathrm{ml}$ of MS basal medium supplemented with $2.5 \mu \mathrm{M} \mathrm{6-}(\gamma$, $\gamma$-dimethylallylamino)-purine (2iP), $30 \mathrm{~g} \cdot 1^{-1}$ sucrose, $12 \mathrm{~g} \cdot 1^{-1}$ agar. After 4 weeks of culture under the same conditions as above, uniformly elongated shoots about $15 \mathrm{~mm}$ long were collected and prepared as microcuttings. The basal leaves were removed and three terminal leaves were left.

Experiment 1: Effect of rooting substrate on rooting rate and root morphology. As rooting substrates, agar, gellan gum, starch, vermiculite and rockwool were tested. A halfstrength MS basal medium supplemented with $30 \mathrm{~g} \cdot 1^{-1}$ sucrose was gelled with $10 \mathrm{~g} \cdot 1^{-1}$ agar, $3 \mathrm{~g} \cdot 1^{-1}$ gellan gum, $120 \mathrm{~g} \cdot 1^{-1}$ starch individually, and $20 \mathrm{ml}$ of medium was dispensed per test tube $(25 \times 150 \mathrm{~mm})$. Twenty milliliters of vermiculite and rockwool were placed in the test tube and moistened with $10 \mathrm{ml}$ of the half-strength MS liquid medium containing $30 \mathrm{~g} \cdot 1^{-1}$ sucrose.

The base of the microcuttings was dipped in $12 \mathrm{~mm}$ indole-3-butylic acid (IBA) in 50\% ethanol for $5 \mathrm{~s}$. Then the microcuttings were inserted into the rooting media. Twenty five microcuttings were used per treatment. After 4 weeks of culture under the same conditions as previously described, the percentage of rooted microcuttings was recorded. Transverse microtome-sections of the roots at a distance of $5 \mathrm{~mm}$ from the root tips were stained with $0.5 \%$ safranine and then observed under a light microscope.

Experiment 2: Effect of concentration of agar and gellan gum on rooting rate and root morphology. A half-strength MS basal medium containing $30 \mathrm{~g} \cdot 1^{-1}$ sucrose was gelled with various concentrations of agar $\left(7,10,13,16 \mathrm{~g} \cdot 1^{-1}\right)$ and gellan gum $\left(2,3,4,5 \mathrm{~g} \cdot 1^{-1}\right)$. Twenty milliliters of the medium was dispensed in a test tube. The procedures for the preparation of the microcuttings and culture conditions were the same as in experiment 1 . After 4 weeks of culture, the rooting rate was recorded and root morphology was observed microscopically.

\section{RESULTS}

\section{Experiment 1: Effect of rooting substrate on rooting rate and root morphology}

The rooting of the microcuttings started after the swelling of the basal ends about 1 week after the initiation of culture. Finally, the rooting rate was highest in the starch medium at $96 \%$ followed by the agar, rockwool and vermiculite media. In the gellan gum medium, only $8 \%$ of the microcuttings rooted (Table 1). Large amounts of calli were produced at the basal

Table 1 Effect of rooting substrate on root growth in vitro. ${ }^{\mathrm{z}}$

\begin{tabular}{lcccc}
\hline Rooting substrate & $\begin{array}{c}\text { Percentage of } \\
\text { rooting } \\
(\%)\end{array}$ & $\begin{array}{c}\text { Root } \\
\text { diameter } \\
(\mu \mathrm{m})\end{array}$ & $\begin{array}{c}\text { Vascular } \\
\text { diameter } \\
(\mu \mathrm{m})\end{array}$ & $\begin{array}{c}\text { Root hair } \\
\text { length } \\
(\mu \mathrm{m})\end{array}$ \\
\hline Gellan gum, $3 \mathrm{~g} \cdot 1^{-1}$ & 8 & $1296 \mathrm{a}^{\mathrm{y}}$ & $304 \mathrm{ab}$ & 264 \\
Agar, $10 \mathrm{~g} \cdot 1^{-1}$ & 76 & $2132 \mathrm{~b}$ & $464 \mathrm{~b}$ & 198 \\
Starch, $120 \mathrm{~g} \cdot 1^{-1}$ & 96 & $2432 \mathrm{c}$ & $756 \mathrm{c}$ & 358 \\
Vermiculite & 56 & $605 \mathrm{a}$ & $163 \mathrm{a}$ & 497 \\
Rockwool & 76 & $746 \mathrm{a}$ & $338 \mathrm{~b}$ & - \\
LSD $(p<0.01)$ & & & & 47.9 \\
\hline
\end{tabular}

\footnotetext{
$z$ The microcuttings were cultured at $27 \pm 1^{\circ} \mathrm{C}$ under a photoperiod of $16 \mathrm{~h}$ at $40 \mu \mathrm{mol}$. $\mathrm{m}^{-2} \cdot \mathrm{s}^{-1}$ with cool white fluorescent tubes.

y Mean separation within column by Duncan's multiple range test at $1 \%$ level.
} 

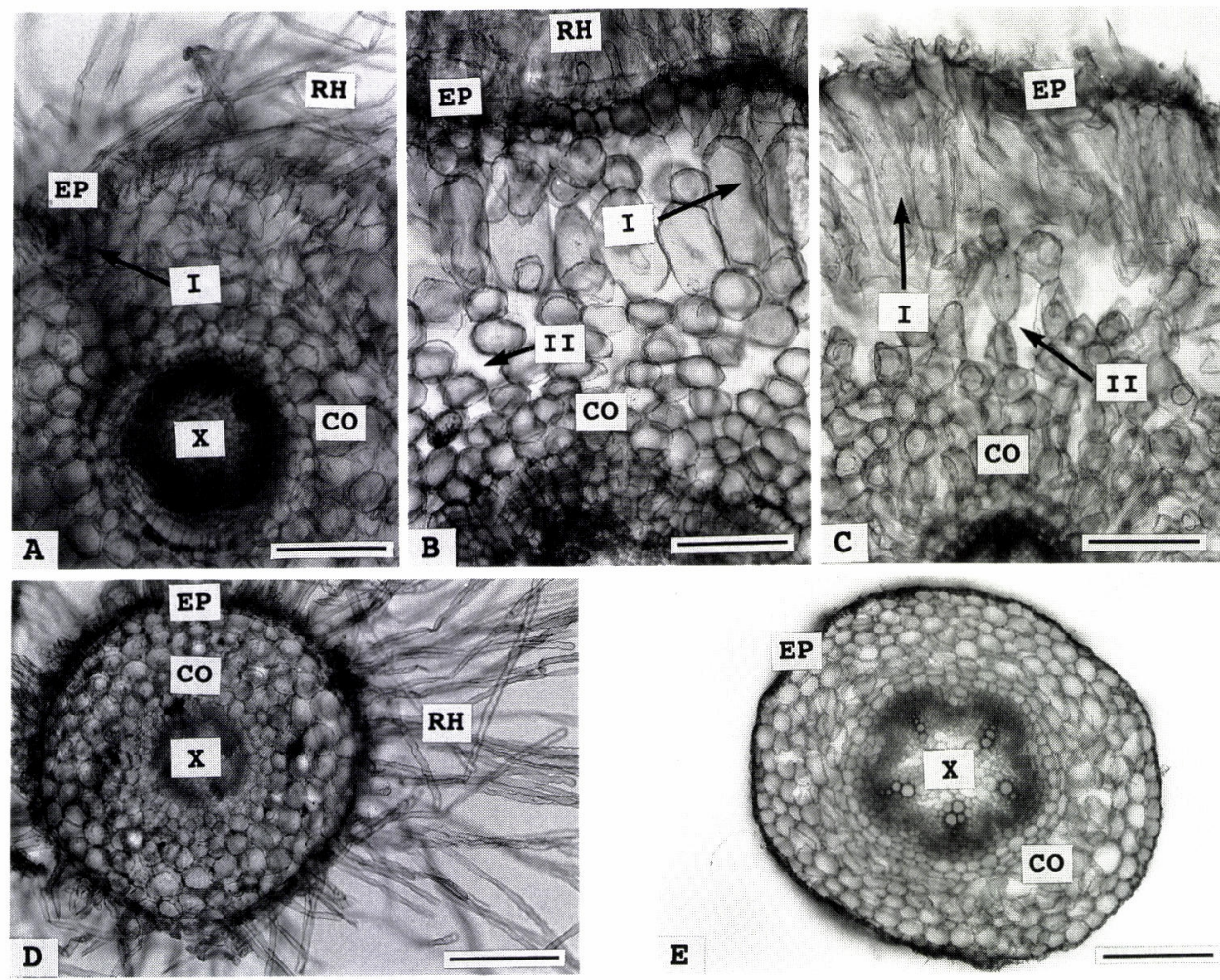

Fig. 1 Transverse sections of papaya roots formed in different rooting substrates.

(A) Three grams per liter gellan gum, (B) $10 \mathrm{~g} \cdot 1^{-1}$ agar, (C) $120 \mathrm{~g} \cdot 1^{-1} \mathrm{starch}$, (D) vermiculite, (E) rockwool. Arrows show (I) hypertrophic cell in subepidermal layer and (II) the unusual expansion of intercellular space. $\mathrm{CO}$, cortex ; $\mathrm{EP}$, epidermis ; RH, root hair ; X, xylem. Bar : $0.5 \mathrm{~mm}$ in (A), (B) and (C); $0.2 \mathrm{~mm}$ in (D) and (E).

end of the microcuttings cultured in the starch, agar and gellan gum media, whereas a small amount of calli was formed in the vermiculite and rockwool media.

Morphologically, the roots formed in the starch, agar and gellan gum media were significantly thicker than those in the vermiculite and rockwool media. The root hairs were longer in the vermiculite than in the other media. In the roots grown in rockwool, no root hairs were found (Table 1). The abnormalities of the inner structure were observed commonly in the roots formed in the starch, agar and gellan gum media. The subepidermal cells showed a considerable hypertrophy accompanied by the unusual expansion of intercellular spaces (Fig. 1). On the other hand, in the vermiculite and rockwool media, no structural abnormality appeared.

\section{Experiment 2: Effect of concentration of agar and gellan gum on rooting rate and root morphology}

The rooting rate was enhanced with increasing concentration of agar in the medium and reached a value of $88 \%$ when $16 \mathrm{~g} \cdot 1^{-1}$ of agar was added. Although no roots occurred in the medium gelled with 2 and $3 \mathrm{~g} \cdot 1^{-1}$ gellan gum, the rooting was also promoted by the increase of the concentration above $4 \mathrm{~g} \cdot 1^{-1}$ (Table 2). In the medium with low concentrations of agar and gellan gum, abundant calli were formed at the basal end of the microcuttings. However 
Table 2 Effect of agar and gellan gum concentration on root growth in vitro. ${ }^{z}$

\begin{tabular}{lcccc}
\hline Rooting substrate & $\begin{array}{c}\text { Percentage of } \\
\text { rooting } \\
(\%)\end{array}$ & $\begin{array}{c}\text { Root } \\
\text { diameter } \\
(\mu \mathrm{m})\end{array}$ & $\begin{array}{c}\text { Vascular } \\
\text { diameter } \\
(\mu \mathrm{m})\end{array}$ & $\begin{array}{c}\text { Root hair } \\
\text { length } \\
(\mu \mathrm{m})\end{array}$ \\
\hline Agar, $7 \mathrm{~g} \cdot 1^{-1}$ & 28 & $1248 \mathrm{a}$ & $506 \mathrm{a}$ & $427 \mathrm{a}$ \\
Agar, 10 $\cdot 1^{-1}$ & 60 & $585 \mathrm{~b}$ & $205 \mathrm{c}$ & $319 \mathrm{~b}$ \\
Agar, 13 g $\cdot 1^{-1}$ & 68 & $988 \mathrm{ab}$ & $300 \mathrm{~b}$ & $199 \mathrm{c}$ \\
Agar, 16 g $\cdot 1^{-1}$ & 88 & $1090 \mathrm{a}$ & $340 \mathrm{~b}$ & $196 \mathrm{c}$ \\
Gellan gum, $2 \mathrm{~g} \cdot 1^{-1}$ & 0 & - & - & - \\
Gellan gum, $3 \mathrm{~g} \cdot 1^{-1}$ & 0 & - & - & - \\
Gellan gum, $4 \mathrm{~g} \cdot 1^{-1}$ & 32 & $1027 \mathrm{a}$ & $636 \mathrm{a}$ & $400 \mathrm{a}$ \\
Gellan gum, $5 \mathrm{~g} \cdot 1^{-1}$ & 72 & $1122 \mathrm{a}$ & $363 \mathrm{~b}$ & $433 \mathrm{a}$ \\
\hline
\end{tabular}

$z$ The microcuttings were cultured at $27 \pm 1^{\circ} \mathrm{C}$ under a photoperiod of $16 \mathrm{~h}$ at 40 $\mu \mathrm{mol} \cdot \mathrm{m}^{-2} \cdot \mathrm{s}^{-1}$ with cool white fluorescent tubes.

y Mean separation within column by Duncan's multiple range test at $1 \%$ level.
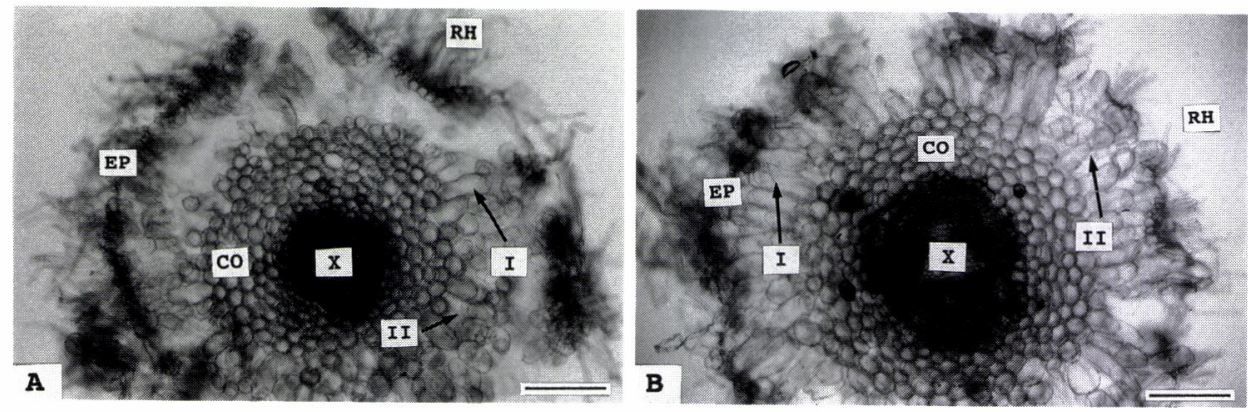

Fig. 2 Transverse sections of roots formed in high concentration of agar and gellan gum media.

(A) Sixteen grams per liter agar, (B) $5 \mathrm{~g} \cdot 1^{-1}$ gellan gum. Arrows show (I) hypertrophic cell in subepidermal layer and (II) the unusual expansion of intercellular space. CO, cortex ; EP, epidermis ; RH, root hair ; X, xylem. Bar : $0.2 \mathrm{~mm}$.

the amount of calli decreased with the increase of the concentration of agar and gellan gum higher than 10 and $2 \mathrm{~g} \cdot 1^{-1}$, respectively.

Although the diameter of the roots was largest in the $7 \mathrm{~g} \cdot 1^{-1}$ agar medium, the roots formed in the other media tested were thicker than those in the vermiculite or rockwool medium in experiment 1 (Table 1, Table 2). Similar abnormal structure of the roots which was observed in experiment 1 was found in both media, even where agar and gellan gum were used at high concentrations. Some cracks in the epidermis also occurred in these media (Fig. 2).

\section{DISCUSSION}

In this study, morphological abnormalities were observed in the roots formed in agar medium. Poor rooting in agar medium has also been reported in several species (McClelland et al., 1990) and the existence of growth-inhibiting substances in agar has been suggested (Hu and Wang, 1983). This factor may result in the suppression of growth in papaya roots in agar and induce the abnormal development of the inner structures. Although the use of gellan gum or starch in place of agar sometimes improved root growth (Huang et al., 1995), the 
abnormalities persisted in this study.

Teo and Chan (1994) reported that the rooting rate could be improved by increasing the concentration of agar in the medium. Although in this experiment, increased concentrations of agar and gellan gum suppressed the callus formation and increased the rooting rate, root morphology was not improved. Therefore, it is considered that the poor aeration of these substrates might be the major cause of abnormal development of roots, rather than the presence of certain inhibiting substances or the low osmotic potential of the medium.

Hypertrophic cell growth was sometimes observed in the stem of the plants which experienced flooding (Kawase, 1974 ; Schaffer et al., 1992). Larson et al. (1993) reported that lenticel hypertrophy of mango was induced by low partial pressures of $\mathrm{O}_{2}$ in the flooded water and was not solely a hydration effect. He also suggested that ethylene generated under anaerobic conditions may be involved in this phenomenon. The marked hypertrophy of subepidermal cells accompanied by the unusual expansion of intracellular spaces which were observed in the roots in agar, gellan gum and starch may occur as the result of the excessive response adapting to the anaerobic condition.

On the other hand, in water melon culture when liquid medium with a vermiculite substrate was used for support and aeration, the root system was significantly improved with stronger branches and extensive root hairs (Barnes, 1979). Yabuki and Kitaya (1984) reported that the vermiculite provided both an adequate aeration and water retention. Furthermore, a high water potential in the leaves of shoot/plantlets cultured in vermiculite medium compared to those in agar and gelrite brought the high number of primary root in Eucalyptus (Kirdmanee et al., 1995). When considering these facts and the results of the current experiment, it is suggested that the selection of a rooting substrate with better air permeability as well

as appropriate water retention is essentially important for the normal root development of tissue-cultured papaya shoots.

\section{REFERENCES}

Barnes, L. R. 1979. In vitro propagation of water melon. Sci. Hortic. 11 : 223-227.

De Winnaar, W. 1988. Clonal propagation of papaya in vitro. Plant Cell Tissue Organ Cult. 12 : 305-310.

Hu, C. Y., Wang, P. J. 1983. Meristem, shoot tip, and bud culture. In "Handbook of Plant Cell Culture" (ed. by Evans, D. A., Sharp, W.R., Ammirato, P.V., Yamada, Y.), Vol. 1. Macmillan Inc., New York, p 177-227.

Huang, L. C., Kohashi, C., Vangundy, R., Murashige, T. 1995. Effects of common components on hardness of culture media prepared with gelrite ${ }^{\mathrm{TM}}$. In Vitro Cell. Dev. Biol. 31 : 84-89.

Kataoka, I., Inoue, H. 1991. Rooting of tissue cultured papaya shoots under ex vitro conditions. Jpn. J. Trop. Agric. 35 : 127-129.

Kataoka, I. 1994. Influence of rooting substrates on the morphology of papaya root formed in vitro. Jpn. J. Trop. Agric. 38 : 251-257.

Kawase, M. 1974. Role of ethylene in induction of flooding damage in sunflower. Physiol. Plant. 31 : 29-38.

Kirdmanee, C., Kitaya, Y., Kozai, T. 1995. Effects of $\mathrm{CO}_{2}$ enrichment and supporting material on growth, photosynthesis and water potential of Eucalyptus shoots/plantlets cultured photoautotrophically in vitro. Environ. Control in Biol. 33 : 133-141.

Larson, K. D., Schaffer, B., Davies, F. S. $1993 . \quad$ Floodwater oxygen content, lenticel hypertrophy, and ethylene evolution from mango (Magnifera indica L.) trees. J. Exp. Bot. 44 : 665-671.

McClelland, M. T., Smith, M. A. L., Carothers, Z. B. 1990. The effects of in vitro and ex vitro root initiation on subsequent microcutting root quality in three woody plants. Plant Cell Tissue Organ Cult. 23 : 115-123. 
Murashige, T., Skoog, F. 1962. A revised medium for rapid growth and bioassays with tobacco tissue culture. Physiol. Plant. 15 : 473-497.

Schaffer, B., Andersen, P. C., Ploetz, R. C. 1992. Responses of fruit crops to flooding. Hortic. Rev. 13 : 257-313.

Teo, C. K. H., Chan, L. K. 1994. The effects of agar content, nutrient concentration, genotype and light intensity on the in vitro rooting of papaya microcuttings. J. Hortic. Sci. 69 : 267-273.

Yabuki, K., Kitaya, Y. 1984. Studies on the control of gaseous environment in the rhizosphere. (1) Changes in $\mathrm{CO}_{2}$ concentration and gaseous diffusion coefficient in soils after irrigation. J. Agric. Meteol. 40 : $1-7$.

\section{〈和文抄録〉}

種々の発根培地支持体におけるパパイア培誉シュートの根の生長

\section{スクサードパドウンサック・片岡郁雄・別府堅治・藤目幸摭・スパダラパン スラナン*}

\section{香川大学農学部，*カセサート大学農学部}

培養条件下でのパパイアの根の生長に及ほす発根培地の支持体の影響を検討した。マイクロ カッティングの発根は基部が肥大した後に開始した. 4 週間培養後の発根率は, デンプン培地で 96\%と最も高く, これに次いで寒天培地, ロックウール培地, バーミキュライト培地の順で高かっ

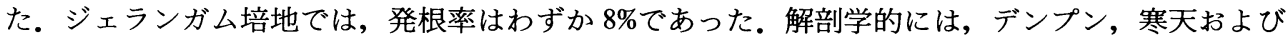
ジェランガム培地では, 根の亜表皮細胞の肥大や表皮の亀裂が観察された。一方，バーミキュライ トおよびロックウール培地では, 根の構造に異常は認められなかった. 寒天およびジェランガムの 濃度を上昇させることにより発根率は増加したが，根の構造的異常は解消しなかった。 